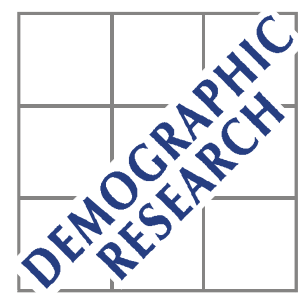

Demographic Research a free, expedited, online journal of peer-reviewed research and commentary in the population sciences published by the Max Planck Institute for Demographic Research Doberaner Strasse 114 · D-18057 Rostock · GERMANY www.demographic-research.org

DEMOGRAPHIC RESEARCH

VOLUME 3, ARTICLE 4

PUBLISHED 4 SEPTEMBER 2000

www.demographic-research.org/Volumes/Vol3/4/

DOI: $10.4054 /$ DemRes.2000.3.4

Determinants of Divorce in a Traditional

Muslim Community in Bangladesh

Nurul Alam

Sajal K. Saha

Jeroen K. van Ginneken

(C) 2000 Max-Planck-Gesellschaft. 


\title{
Determinants of Divorce in a Traditional \\ Muslim Community in Bangladesh
}

\author{
Nurul Alam ${ }^{1}$ \\ Sajal K. Saha ${ }^{1}$ \\ Jeroen K. van Ginneken ${ }^{2}$
}

\begin{abstract}
This study examines the effects of spouses' prior marital status and socio-demographic characteristics on the risk of divorce of 1762 Muslim marriages recorded in 1982-83 in Teknaf, Bangladesh. Grooms' prior marital status was categorized into never married, divorced, widowed or polygynous (already cohabiting with one or more wives) and brides' prior marital status was categorized into never married, divorced or widowed. Divorce was recorded by following the marriages prospectively for five years. Due to the fact that a longitudinal study design was used, the quality of the information presented here is considered to be high. A discrete-time hazard logistic model was used to estimate the effects of spouses' prior marital status and a number of socio-demographic variables on risk of divorce. Polygynous marriage, remarriage and divorce were found to be common in this traditional Muslim community. The odds of divorce were 2.5 times higher for grooms' polygynous marriages and 1.6 times higher for brides' remarriages compared to their peers' first marriages. The odds of divorce decreased with marriage duration. The groom's and bride's low socio-economic status, illiteracy, and early age at marriage increased the odds of divorce. The odds of divorce were much higher if there was no birth in the preceding six months.
\end{abstract}

\footnotetext{
${ }^{1}$ Health and Demographic Surveillance Programme (HDSP), International Centre for Diarrhoeal Disease Research, Bangladesh (ICDDR,B),

${ }^{2}$ Former head of HDSP, ICDDR,B, and currently with the Netherland Interdisciplinary Demographic Institute (NIDI), The Hague Address for Correspondence:

Nurul Alam; HDSP, ICDDR,B; GPO Box 128, Dhaka 1000; Bangladesh; Email: nalam@icddrb.org;

Fax: 8802886050
} 


\section{Introduction}

Studies which have been carried out in Bangladesh on the risk of divorce are limited to first marriages or do not distinguish between first, second or more and polygynous marriages [Shaikh et al. 1985, Bhuiya et al. 1999]. Very little is, therefore, known in Bangladesh about the stability of polygynous marriages and remarriages. Several studies in USA report that the probability of divorce was higher for second than first marriages [Martin and Bumpass 1989, McCarthy 1978, Bumpass and Sweet 1972]. In Bangladesh where a woman's position in the family and society is quite low, a gender difference in stability of remarriages of previously divorced persons is likely. Considering the growing proportion of marriages that are remarriages or polygynous marriages, there is a need for more empirical analysis of why the remarriage-divorce cycle occurs and why remarriages are divorce-prone.

The International Centre for Diarrhoeal Disease Research, Bangladesh (ICDDR,B) possesses unique longitudinal demographic data sets of high quality from two culturally different rural areas, Teknaf and Matlab, which make it possible to undertake studies on these topics. Differences in nuptiality patterns between Teknaf and Matlab are shown in Table 1.

\section{(Table 1 here )}

Comparison of marriages and divorces recorded in Teknaf and Matlab in 1982-83 reveals higher rates of divorce, remarriage and polygyny in the former than in the latter area. Different nuptiality patterns reflect the value systems prevailing in the two rural areas and warrant local-level explanations and separate assessment of the effects of brides' and grooms' prior marital status on risk of divorce.

Objectives: The objectives of this study are to determine the impact of spouses' prior marital status and various socio-demographic factors on marital stability in Teknaf, Bangladesh. We hypothesize that spouses' prior marital status, other things being equal, affects the stability of current marriages. Moreover, in view of the fact that Bangladesh is a male-dominated society we also expect a difference in divorce rates by gender: men will divorce more frequently than women and divorce rates will be particularly high in polygynous marriages. Identification of characteristics of spouses associated with a higher risk of divorce may help to plan remedial actions to reduce divorce and its adverse consequences for divorced persons and their children. 


\section{Overview of factors which may influence divorce}

Muslim Marriage Customs and Laws: The joutuk or dowry plays a key role in the arrangement of marriages in Bangladesh. The dowry is an agreement between the bride's and the groom's family whereby the bride's family agrees to pay a certain amount of money and/or goods in kind to the groom's family [Aziz and Maloney 1985]. Though the practice is illegal under Muslim and state law, it is widespread in Bangladesh. The practice has consequences for the risk of divorce [Bhuiya et al. 1999].

Marriages as well as divorces can be registered with the government through the civil registration system, but most of those events are not registered. In cases where they are not, they are enacted through marriage ceremonies following existing religious and social customs and procedures.

Muslim Divorce Customs and Laws: Divorce of a Muslim marriage is an option which is available to spouses. The process of divorce is usually lengthy and hazardous starting with quarrels followed by mental and physical insults to women, followed by separation and, finally, leading to divorce. Divorce in Muslim marriages is governed by the laws of Islam which traditionally grant more opportunities to men than to women. Women are destined to play a subordinate role in marital life. A woman, of course, can seek divorce in cases where the husband deserts her, fails to maintain her, abjures her or if he is impotent.

Various rules and procedures exist which deal with the obligations of the marriage partners in general and the husband in particular in case a divorce takes place. The mehr plays an important role here. The mehr deals with the obligations of the marriage partners in general and of the groom in particular in case divorce may occur. A key element in the mehr is a specification of the amount of money which the groom pledges to give to his bride in case the marriage will fail. Determination of the mehr is mandatory according to Muslim law and is fixed by the parents or guardians of both the groom and the bride at the time of arrangement of the marriage [Aziz and Maloney 1985]. In practice, however, the groom's party often has the upper hand when negotiating the mehr and in a number of cases of divorce the groom's party does not adhere to what was agreed upon.

Women's Position in the Family: In rural Bangladesh, the husband is the breadwinner and the wife is the primary home-keeper. She depends on her husband for livelihood, and there are hardly any other possibilities for her to make a living. Moreover, divorced persons are looked down upon in the society with an obvious gender difference. Divorce of a woman damages her as well as her family's prestige. It may lower prospects of marriage of her younger sisters with the most eligible grooms. Chances of remarriage after divorce are usually lower for women than for men and this holds for Bangladesh as well as elsewhere [Shaikh 1995, Chamie and Nsuly 1981]. One can expect that the wife's economic dependence on the husband and the fear of subsequent 
poverty and her weaker position in the marriage and economic markets are powerful deterrents for her from leaving the husband, however unhappy the marriage. She compromises more than her husband to keep the marriage intact. Therefore, the decision of divorce is likely to be initiated more often by the husband than by the wife.

The practice of the dowry is a social curse to women contributing to marital tensions and divorce. It reflects women's economic dependence on men. In a number of cases the bride's party fails to pay the dowry demanded by the groom's party. In a community survey in Matlab, 20 per cent of 126 married women and 35 per cent of 79 divorced women reported conflict within marriage due to non-fulfillment of the demand for dowry [Bhuiya et al. 1999]. Marital discord can lead to domestic violence, which may force the bride to flee from the husband's home and accept divorce. Divorce can, therefore, be seen as a marker of extreme mental and physical insults, particularly to women in rural Bangladesh.

Polgygyny: Polygyny is characteristic for Teknaf. It increases the possibilities of marriage and remarriage for women. It reflects a groom's personal taste. Polygynous marriages are likely to be less stable than monogamous marriages for several reasons. Competition between co-wives for husband's love and affection may raise tensions leading to quarrels at home. A polygynous man, on the other hand, may view wives more as bed-partners than life-partners. If this is the case, keeping the marriage intact may be less important to him. This kind of view weakens the bonds of marriage and marriage and divorce are reduced to mere formalities leading to high probabilities of remarriage and divorce. The polygyny-divorce relationship has hardly been studied in Bangladesh for lack of data and it is one of the objectives of this study.

Other Factors Influencing Risk of Divorce: There is evidence that spouses' previous marital disruptions affect the stability of their current remarriage. One study in the USA found that the ratio of divorces per 100 marriages was 16.6 when both partners were in a first marriage and 34.9 when both had been previously divorced once [McCarthy 1978]. Another study reports that homogamous marriages (a single person choosing another single or a divorced person choosing somebody else who is divorced) were more stable than heterogamous marriages [Chamie and Nsuly 1981]. An analysis of the outcome of marriages in the USA showed that a prior marriage of the husband made a significant net addition to the probability of marriage dissolution in USA [Bumpass and Sweet 1972]. What causes remarriages to be more divorceprone than first marriages is in debate. Martin and Bumpass [1989] argue that people in remarriages carry with them the characteristics (early age at first marriage, low education and so on) that raised the probability of their first marriage dissolving. If this is the case, then remarriages should not be divorce prone when age at marriage and level of education are controlled. White and Booth [1985], argue that the internal dynamics of second marriages (largely because of stepchildren) were more problematic than first marriages. In Bangladesh, the 
causes of divorce of remarriages, particularly polygynous marriages could be different than the causes of divorce of remarriages in developed countries.

In rural Bangladesh, teenage marriage is common and desired. The 1982-83 marriage cohort in Teknaf revealed that median age at first marriage was 16 years for brides and 22 years for grooms. Very young brides and grooms may not be able to cope emotionally with the heavy load of responsibilities involved in marital life. Their inability to cope with these new responsibilities may raise tensions and thus, affect marital stability. It is also to be expected that having an education and living in favourable socioeconomic conditions may help them to cope with marital responsibilities and thus, keep the marriage intact, particularly in early years of marital life. The divorce risk was found to decrease as duration of marriage increases in Bangladesh and elsewhere [Bhuiya et al. 1999, Menken et al. 1981].

Marriages are more stable if couples have children than when they do not have children. This was one of the conclusions of the review of the literature on causes of divorce [White, 1990]. In the United States [White and Booth 1985, Wineberg 1988, Waite and Lillard 1991] and in Sweden [Andersson 1995] it was found that the presence of young children was associated with lower risks of divorce. The presence of children younger than six years decreased the risk of marital dissolution in Australia, but once the employment activity of the wife was simultaneously taken into account, the effect of having young children disappeared [Bracher et al. 1993]. 


\section{Methods}

The data of this study came from five villages of Teknaf where ICDDR,B maintained a demographic surveillance system (DSS) during 1976-89. It is at the south-eastern tip of Bangladesh bordering Myanmar. People are mostly illiterate, conservative Muslim. Men are employed in agriculture and fishing in the nearby Naf river and the Bay of Bengal while women are engaged in household chores. Teknaf has higher fertility and infant mortality than Matlab [Rahman et al. 1985-1986, Shaikh et al. 1984 and 1985].

Teknaf-DSS recorded vital events, migrations, marriages and marital dissolution by means of monthly household visits. Marriage refers to a union, which is established by civil or religious procedures while divorce is dissolution of marital union through civil, religious or social procedures. Most marriages and divorces are not registered with the government civil registration system. A total of 1762 marriages were recorded by Teknaf-DSS during 1982-83; they were followed up in the period 1982-1988 to determine changes in marital status as well as outmigration and death of one or both of the spouses.

The marriage form contained information on marriage related events as well as on previous marital status of the groom and the bride and their ages at current marriage, years of schooling, occupations and kinship. Polygyny was determined by considering information on the groom's marital status at the time of the current marriage (i.e., in 1982-83). The groom's prior marital status was categorized into never married, divorced, widowed or polygynous (already married and cohabiting with one or more wives in addition to current wife). The bride's marital status prior to the current marriage was categorized into never married, divorced or widowed.

Information on live births born to the 1982-83 marriage cohort during the first five years of marriage was obtained by matching marriage records with birth records of 1982-88. Newly married women were categorized into a group which had a live birth in the preceding six months and another group which had not.

The Teknaf Household Socioeconomic Census in 1982 provided information on socioeconomic status. Ownership of land was coded 1 if the family owned more than 0.30 acre of land and 0 if they had less. Ownership of fishing boat, fishing net, betel leaf garden, betel nut garden or receipt of remittances from abroad by groom's family were coded 1, otherwise it was coded as 0 . An index of the number of economic assets owned by the groom's family was used to determine household economic status. Groom's years of schooling was grouped into none or some. Since nearly all brides were illiterate, (4.9 per cent of brides had some schooling), bride's education was not included in the analysis.

Data Analysis: During the five-year follow-up period of 1762 Muslim marriages recorded in 1982-83, 40 marriages were disrupted due to death of one spouse, and another 28 marriages due to emigration of both partners. Marriages, which were lost to the follow-up were excluded 
from the analysis subsequent to their emigration or death of spouse. Marriage duration was determined in segments of six months. The crude effects on risk of divorce of the predisposing variables (duration of marriage, bride's and groom's previous marital status, groom's education and household wealth, bride's fertility status and kinship between partners) were estimated by calculating divorce rates per 100 marriage-years (or per 200 six-months segments).

The net effects of the independent variables on the risk of divorce of marriages were estimated using a discrete-time hazard logistic model. All the variables except groom's age at marriage, were made binary, and so was the dependent variable — divorced/intact marriage. The initial logistic model contained all the variables and the interactions between duration of marriage and spouses' previous marital status, education and household assets. Interactions of insignificant coefficients were eliminated one by one if the difference in likelihood ratio statistics between the two nested models (the latter is the subset of the former) was not significant (chisquare $<0.1)$. The final logistic model contained all the variables and the significant interactions only. 


\section{Results}

Table 2 shows the gender difference in selection of marriage partner. Never married grooms married never married brides in 93 per cent of cases (949 out of 1020) whereas never married

(Table 2 here)

brides married never married grooms in 78 per cent of cases (949 out of 1220). Likewise, the remarriage rate per 100 marriages was $42(17+5+21)$ for grooms and $31(3+28)$ for brides. The incidence of polygyny was 17 per 100 marriages of grooms. Nearly one-third of the brides of polygynous unions was never married (86 out of 293), 60 per cent were divorced women (180 out of 293) and the rest were widowed. Grooms chose brides of similar marital status (homogamous marriages) in 64 per cent of all marriages.

The divorce rate (per 100 marriage-years) showed an inverse relationship with duration of marriage; the rate was especially high during the first two years of marriage (Table 3). Marriages experiencing higher than average divorce rates were polygynous

\section{(Table 3 here)}

marriages followed by remarriages of brides who were divorced or widowed before. The divorce rate was found to be somewhat higher if grooms were illiterate. The divorce rate during 12-59 months of marital life was lower if brides had had a live birth in the preceding six months than if brides had not had a live birth.

Spouses' age at marriage may have a bearing on the divorce rate. Since bride's and groom's age at marriage was found to be strongly correlated $(r=0.74)$, and bride's age was not significantly related to the divorce risk when controlling for groom's age (data not shown), the bride' s age was not included in multiple logistic regression analysis of divorce.

Table 4 shows that after adjustment of bride's and groom's predisposing factors

\section{(Table 4 here)}

duration of marriage was inversely related to the odds of divorce. The odds were 2.47 times higher if grooms were polygynous men than if grooms were first-time married men. The odds were 1.6 times higher if brides were widowed or divorced before than if brides were never married prior to the current marriage except when marriage duration was 24-35 months. The 
odds of divorce were higher, but not statistically significant, if brides were widowed than if brides were divorced before (data not shown). This result is based on a small number of remarriages of widowed women. Groom's age at marriage and kinship between spouses were negatively related to divorce risks, although weakly. Groom's schooling and high household socioeconomic status led to lower odds of divorce except when marriage duration was 12-23 months.

Because of the high probabilities of divorce of polygynous unions and bride's remarriages, the relationship between fertility and divorce was, therefore, examined using first marriages of both partners lasting more than one year (Table 5). The result shows that

\section{(Table 5 here)}

the odds of divorce for women who had had a live birth in the preceding six-months period were one-third compared to women who had not had a live birth. Among women having a live birth, the odds of divorce were lower, but not significant, for women who had a son than for women who had a daughter (data not shown). 


\section{Discussion}

Levels of Divorce: The divorce rate is found to be inversely related to duration of marriage. This has also been found elsewhere [McCarthy 1978, Menken et al. 1981, Bhuiya et al. 1999]. The least satisfactory marriages end in divorce first thereby reducing the proportion of the high-risk marriages among the surviving unions. When newly wed partners discover that they are incompatible whatever be the cause, they opt for divorce rather early in the marriage. In rural Bangladesh, marriage makes the bride live in the husband's home and with in-laws. The in-laws and relatives expect her to adjust to her new situation and demand a lot from her. Her failure to adjust to in-laws and to satisfy them can cause marital discord and the result of which is illtreatment to her by her husband or in-laws leading to divorce.

Polygyny and Divorce: Polygyny is a special feature of Muslim society and is allowed on condition of the husband's equal treatment of all his wives. Infertility, particularly inability to give birth of a male child and chronic illness of the wife are two main reasons which enhance the divorce risk. They can lead either to a marriage of the husband to a second wife (and becoming a polygynous marriage) or to a divorce of the previous wife followed by another marriage. In Teknaf, 17 per cent of the current marriages were polygynous as opposed to five per cent in Matlab. Of the polygynous men, 26 per cent were in their twenties, and 40 per cent in their thirties. The high incidence of polygyny at younger ages of husbands is much more due to widely accepted norms and values held by men in this community than to wives' infertility or chronic illness.

Polygynous marriages were found to be divorce-prone; the odds of divorce were 2.5 times higher for polygynous unions than for monogamous unions other things being equal. A marriage in which the husband already had one or more than one wife faces more complex adjustment problems than a marriage with a man having no other wife. Moreover, polygynous men have less to lose from divorcing one of the wives. They also tend to have a lower commitment to marriage as an institution and can more easily disregard the stigma of divorce and remarriage. High tensions among co-wives and deeply ingrained attitudes of polygynous men towards women and marriage in general may raise the divorce rate. What remains unknown is whether the high risk of divorce of polygynous marriages is caused by complex adjustment between co-wives or by attitudes of polygynous men to women and marriage as institution. Future studies should attempt to deal with this issue.

In Nigeria, it has been found that polygynous unions with two wives were the most stable whereas unions with three or more wives were associated with the highest rate of disruption [Brandon 1991]. In our study population, unions with three or more wives simultaneously exhibited higher divorce rate, but occurred less frequently than unions with two wives. 
Spouses' History of Marital Disruption: Spouses who already experienced a divorce in their earlier marriage probably faced substantial adjustment problems with which they were unable to cope. We hypothesize that remarriages exposed them to the same problems and for this reason they remain vulnerable to divorce. While expecting high risks of divorce of remarriages, one must take into account that in rural Bangladesh women are aware of the lower prospects of remarriage for them than for men and this may force women to compromise to keep the marriage intact. Reconciliation is more likely for wives than husbands since the cost of divorce is higher for women and alternatives are hardly available (women are economically and socially dependent). One of the underlying causes for this is undoubtedly the unequal position of women compared to men in Bangladesh society. Our data exhibit a gender difference in the risk of divorce of remarriages. While grooms who remarried after a divorce or after becoming a widower did not have a higher risk of divorce than grooms who married for the first time, brides who remarried (after divorce or becoming a widow) had a higher risk of divorce than brides who married for the first time.

The difference in divorce propensity between previously divorced brides and grooms may have several explanations. An important one is related to the weaker position of the wife in the husband's family. She is blamed for every trivial fault; for such faults her husband is less likely to be blamed. Too much blame expressed too frequently puts her marriage in discord leading towards divorce. Of the brides who were divorced before, 42 per cent were still in their teens. Their inability to live up to the expectations of their husbands and in-laws may have brought marital discord leading eventually to divorce as a solution to marital unhappiness. Another possibility is that the presence of children from a previous marriage may make her stay more problematic than that of her peers who had married for the first time. Higher instability of remarriages of women than men may be explained by men's abuse of the right to divorce and women's powerlessness.

Age at Marriage: As found in other studies [Shaikh 1995, Bhuiya et al. 1999, White 1990], the groom's age at marriage was inversely related to the risk of divorce. Young grooms tended to marry young brides. Many grooms were perhaps too young to be able to carry the heavy load of responsibilities involved in marital life. Divorce is likely to be more common among couples who are poorly prepared to undertake such responsibilities. This finding is consistent with the common explanation that young age at marriage may be associated with poor role performance as a spouse.

Groom's Education and Household Socioeconomic Status: Higher levels of education of grooms were associated with lower odds of divorce in the first year of marital life. Literacy in Teknaf was very low (14 per cent of grooms had one to two years of schooling) and nearly all brides were illiterate. The odds of divorce were higher if grooms came from households with fewer assets. Shortage of economic resources which are needed for a successful beginning of 
marital life, may have raised tensions and caused unhappiness. Moreover, it could be that poor grooms were less tolerant and respectful to their wives (and vice versa) than rich grooms. Inverse relationships of education and socioeconomic status with divorce have also been reported in other studies conducted in Bangladesh, the USA and elsewhere [see e.g., White 1990; Bhuiya et al. 1999].

Infertility and Divorce: In rural Bangladesh, child bearing soon after marriage is desired. Contraceptive use before first birth is in general very low and was in the study population even lower than the national average derived from the Demographic and Health survey conducted in 1993/1994 [Mitra et al. 1994]. The birth of a child after marriage may signify a degree of spousal satisfaction that is conducive to marital stability. Our analysis reveals that the odds of divorce were much lower if women had a live birth in the proceeding six-months than if women had not had a birth. The birth of a child helps to keep couples together at least until they are older. This result is in accordance with findings in the USA and Sweden [White 1990, Waite and Lillard 1991, Andersson 1995].

Limitations of this Study: An anthropological study carried out in rural Bangladesh reported that the most desirable traits in a bride are to be young and to have physical beauty and lineage. For the groom wealth and earning capacity are desired most often [Aziz and Maloney 1985]. However, data especially on these physical, personal and family attributes of grooms and brides were not available in this study. These attributes were prime considerations when parents and relatives of the partners arranged the marriage for them. This point was also made by White [1990] in her review of research on divorce in the 1980s although she focused more on the need to do research on processes of marriage formation and dissolution than on desirable attributes. She also stressed to conduct more studies on the impact of the processes of family formation on the processes which lead to divorce. One study in Maltab revealed that the process of marriage formation and spouses' behaviour after marriage influenced the divorce risk [Bhuiya et al. 1999]. This finding is in keeping with our result that kinship between partners, which facilitate seeing and knowing each other, was associated with a lower risk of divorce. While the process of marriage formation is important, groom's polygamy and bride's divorce in a previous marriage appeared to be the most significant antecedents of divorce in the study population.

Another limitation of our study is that since the follow-up period was five years, the longterm effects of various determinants on risk of divorce could not be examined. One can expect that reasons for divorce change with duration of marriage. Nevertheless, high rates of divorce of polygynous marriages and of brides' remarriages were evident and may be explained by the unequal position of women in the family and society. 


\section{Acknowledgments}

The Demographic Surveillance System (DSS) in Teknaf was supported by the Canadian International Development Agency (CIDA) and the International Centre for Diarrhoeal Diseases Research, Bangladesh (ICDDR,B). Data collection and analyses were carried out under the auspices of ICDDR,B, which is supported by countries and agencies which share its concern for the health and population problems of developing countries. The authors acknowledge the assistance of the Teknaf field staff, particularly Mr. Yeakub Patwari - the Field Supervisor. 


\section{References}

Andersson, G. (1995), Divorce-risk trends in Sweden 1971-1993. European Journal of Population 11, pp. 293-311.

Aziz, K.M.A. and C. Maloney (1985), Life stages, gender and fertility in Bangladesh. Monograph No. 3. Bangladesh. Mohakhali, Dhaka 1212: International Centre for Diarrhoeal Disease Research.

Bhuiya A, M. Chowdhury, M. Momen and Khatun (1999), Marital disruption in a rural area of Bangladesh: predisposing factors and consequences on women's lives. Scientific Report No. 85. Bangladesh, Dhaka: International Centre for Diarrhoeal Disease Research.

Bracher, M., G. Santow, S. P. Morgan and J. Trussell (1993), Marriage and dissolution in Australia: models and explanations. Population Studies 47, pp. 403-425.

Brandon, A.J. (1991), The polygyny-divorce relationship: A case study of Nigeria. Paper presented to Population Association of America, March 21-23, 1991, Washington DC.

Bumpass, L.L and J.A. Sweet (1972), Differentials in marital stability: 1970. American Sociological Review, 37, pp. 754-766.

Chamie, J. and S. Nsuly (1981), Sex differences in remarriage and spouse selection. Demography, 18, pp. 335-348.

Martin, T. C. and L.L. Bumpass (1989), Recent trends in marital disruption. Demography 26, pp. 37-51.

McCarthy, J. (1978), A comparison of the probability of the dissolution of first and second marriages. Demography 15, pp. 345-359.

Menken, J., J. Trussell, D. Stempel and O. Babakol (1981), Proportional hazard life table: An illustrative analysis of socio-demographic influences on marriage dissolution in the United States. Demography 18, pp. 181-200.

Mitra, S. N., M. N. Ali, S. Islam, A. Cross and T. Saha (1994), Bangladesh Demographic and Health Survey 1993-94. National Institute of Population Research and Training (NIPORT), Dhaka, Bangladesh, Mitra and Associates, Dhaka, Bangladesh and Macro International, Calverton, Maryland.

Rahman, M., S.A. Chowdhury, Y. Patwari et al., (1985-1986). Demographic Surveillance System - Teknaf: Vital Events and Migration 1982 and 1983. Scientific Report Nos - 65 and 66. International Centre for Diarrhoeal Disease Research, Bangladesh. Mohakhali, Dhaka 1212.

Rahman, O. (1993), Excess mortality for the non-married in rural Bangladesh. International Journal of Epidemiology 22(3), pp. 445-456.

Shaikh, K. (1995), Nuptiality Patterns and Fertility Behaviour in Rural Bangladesh. Ph.D. Thesis, Bombay: International Institute of Population Sciences. 
Shaikh, K., G. Mostafa, A.M. Sarder and B. Wojtyniak (1984), Demographic Surveillance System - Matlab: Vital Events and Migration Tables 1982. Scientific Report No - 62. International Centre for Diarrhoeal Disease Research, Bangladesh. Mohakhali, Dhaka 1212.

Shaikh, K., G. Mostafa, A. Bhuiya et al., (1985), Demographic Surveillance System - Matlab: Vital Events and Migration Tables 1983. Scientific Report No - 64. International Centre for Diarrhoeal Disease Research, Bangladesh. Mohakhali, Dhaka 1212.

Waite, L. J. and L. A. Lillard (1991) Children and marital disruption. American Journal of Sociology 96, pp. 930-953.

White, L. (1990), Determinants of divorce: A review of research in the eighties. Journal of Marriage and the Family 52, pp. 904-912.

White, L. and A. Booth (1985), The transition to parenthood and marital quality. Journal of Family Issues 6, pp. 435-449.

Wineberg, H. (1988), Duration between marriage and first birth and marital stability. Social Biology 35, pp. 91-102. 


\section{Table 1:}

Nuptiality patterns in Teknaf and Matlab in 1982-83

\begin{tabular}{llrr}
\hline Nuptiality & & Teknaf & Matlab \\
\hline Remarriage rates (per 100 marriages): & brides & 32.4 & 15.6 \\
& grooms & 44.0 & 25.4 \\
Polygynous marriages per 100 marriages & 17.5 & 5.0 \\
Divorce per 100 marriages & & 30.2 & 15.9 \\
Mean age at first marriage (in years): & brides & 16.3 & 17.8 \\
& grooms & 22.2 & 24.8 \\
\hline
\end{tabular}

Sources: Rahman et al. 1985-1986, Shaikh et al. 1984 and 1985.

\section{Table 2:}

Distribution of current marriages (recorded in 1982-83) by spouses' prior marital status

\begin{tabular}{|c|c|c|c|c|c|}
\hline \multirow{2}{*}{$\begin{array}{l}\text { Grooms' previous } \\
\text { marital status }\end{array}$} & \multicolumn{5}{|c|}{ Brides' previous marital status } \\
\hline & $\begin{array}{l}\text { Never married } \\
(=1 \text { st marr.) }\end{array}$ & $\begin{array}{c}\text { Widowed } \\
(=2 \text { nd + marr. })\end{array}$ & $\begin{array}{c}\text { Divorced } \\
(=2 n d+\text { marr. })\end{array}$ & All & \%) \\
\hline Never married (= 1st marr.) & 949 & 6 & 65 & 1020 & $(58)$ \\
\hline Married (= polygynous m.) & 86 & 27 & 180 & 293 & (17) \\
\hline Widowed (= 2nd + marr. $)$ & 17 & 13 & 56 & 86 & (5) \\
\hline Divorced (= 2nd + marr.) & 168 & 10 & 185 & 363 & (21) \\
\hline All $(\%)$ & 1220 & 56 & $(28)$ & 1762 & $(100)$ \\
\hline
\end{tabular}


Table 3:

Percentage distribution of the covariates and divorce rate per 100 marriage-years (total marriage-years $=7137$ )

\begin{tabular}{lrr}
\hline Covariate & Marriage-years (in \%) & Divorce rate \\
\hline All & 100.0 & 6.3 \\
Duration of marriage: & & \\
0-11 months & 23.8 & 10.7 \\
12-23 months & 21.1 & 9.2 \\
24-35 months & 19.2 & 5.3 \\
36-47 months & 18.2 & 2.5 \\
48-59 months & 17.7 & 2.0 \\
Bride's prior marital status: & & \\
never married (=1st marr.) & 71.8 & 5.1 \\
widowed (=2nd + marr.) & 2.7 & 10.8 \\
divorced (=2nd + marr.) & 25.2 & 8.9 \\
Groom's prior marital status: & & \\
never married (= 1st marr.) & 60.8 & 5.0 \\
married (= polygynous m.) & 13.9 & 13.3 \\
widowed (=2nd + marr.) & 5.0 & 4.5 \\
divorced (=2nd + marr.) & 20.3 & 5.8 \\
Kinship: & & \\
no & 77.6 & 6.7 \\
yes & 22.4 & 5.1 \\
Groom's education: & & \\
none & 85.6 & 6.5 \\
some & 14.4 & 5.0 \\
Groom's household assets: & & \\
none & 60.0 & 7.2 \\
some & 27.8 & 9.6 \\
unknown & 12.2 & 7.0 \\
Fertility status & & \\
yes & 81.3 & \\
no & 18.7 & \\
\hline
\end{tabular}

a Marriage-years observed before 12 months of marriage are excluded and births occurring less than one year after marriage are recorded as having taken place at the 12th month of marriage. 
Table 4:

Logistic model odds ratios (and 95 per cent confidence intervals) of divorce on covariates

\begin{tabular}{|c|c|c|}
\hline \multirow{2}{*}{$\begin{array}{l}\text { Covariate } \\
\text { Marriage duration dummies (omitted category: 0-11 months): }\end{array}$} & \multicolumn{2}{|c|}{ Odds ratio $(95 \% \mathrm{Cl})$} \\
\hline & & \\
\hline $12-23$ months & $0.73^{*}$ & $(0.56-0.95)$ \\
\hline 24-35 months & $0.6^{* *}$ & $(0.44-0.81)$ \\
\hline $36-59$ months & $0.21^{* *}$ & $(0.16-0.29)$ \\
\hline \multicolumn{3}{|l|}{ Bride's prior marital status: } \\
\hline widowed/divorced (yes $=1 ;$ no $=0$ ) & $1.6^{*}$ & $(1.22-2.08)$ \\
\hline \multicolumn{3}{|l|}{ Groom's prior marital status: } \\
\hline polygynous $($ yes $=1 ;$ no $=0$ ) & $2.47^{\star *}$ & $(1.82-3.37)$ \\
\hline widowed/divorced (yes $=1 ;$ no $=0$ ) & 1.07 & $(0.8-1.45)$ \\
\hline \multicolumn{3}{|l|}{ Kinship: } \\
\hline$($ yes $=1 ;$ no=0 $)$ & $0.76^{*}$ & $(0.59-0.97)$ \\
\hline Groom's age (range $18-65$ years) & $0.98^{* *}$ & $(0.97-0.99)$ \\
\hline \multicolumn{3}{|l|}{ Groom's education: } \\
\hline$($ some $=1 ;$ none $=0)$ & $0.63^{*}$ & $(0.42-0.93)$ \\
\hline \multicolumn{3}{|l|}{ Groom's household assets: } \\
\hline$($ some $=1 ;$ none $=0)$ & $0.54^{*}$ & $(0.4-0.74)$ \\
\hline (unknown $=1$; none $=0$ ) & 1.02 & $(0.76-1.36)$ \\
\hline \multicolumn{3}{|l|}{ Interactions: } \\
\hline $\begin{array}{l}\text { marriage duration of } 24-35 \text { months } \times \text { groom's divorce } \\
\text { status }\end{array}$ & $0.41^{*}$ & $(0.19-0.86)$ \\
\hline marriage duration of $12-23$ months $x$ groom's education & $1.84^{*}$ & $(1.0-3.39)$ \\
\hline marriage duration of $12-23$ months $x$ household asset & $1.71^{*}$ & $(1.03-2.84)$ \\
\hline \multicolumn{3}{|l|}{ Comparison of models: } \\
\hline \multicolumn{3}{|l|}{ Model with interactions } \\
\hline _ $\quad$ likelihood statistics (df) & 3723.0 & $(14260)$ \\
\hline \multicolumn{3}{|l|}{$\overline{\text { Model without interactions }}$} \\
\hline _ likelihood statistics (df) & 3737.3 & (14263) \\
\hline$\overline{\text { Difference } \chi^{2}}$ & 14.3 & (3) \\
\hline
\end{tabular}

Note: The odds ratio's of the reference categories are equal to 1.00 and consist of 'no' or 'none' (value $=0$ ) except for marriage duration and groom's age. In the case of groom's and bride's prior marital status the reference category is never married $(=0)$.

* $\quad P<0.05$

** $\quad \mathrm{P}<0.01$. 


\section{Table 5:}

Logistic model odds ratios (and 95 per cent $\mathrm{CI}$ ) of divorce of first marriages of spouses on bride's fertility status and other covariates (included were marriages which did not end in divorces in the first year)

\begin{tabular}{|c|c|c|}
\hline \multirow{2}{*}{$\begin{array}{l}\text { Covariate } \\
\text { Birth in previous } 6 \text { months }^{\text {a: }} \text { : }\end{array}$} & \multicolumn{2}{|c|}{ Odds ratio $(95 \% \mathrm{Cl})$} \\
\hline & & \\
\hline$($ yes $=1 ;$ no $=0)$ & $0.33^{* *}$ & $(0.23-0.49)$ \\
\hline \multicolumn{3}{|c|}{ Marriage duration dummies (omitted category: $12-23$ months): } \\
\hline 24-35 months & 1.00 & $(0.71-1.64)$ \\
\hline 36-59 months & $0.45^{\star *}$ & $(0.29-0.72)$ \\
\hline \multicolumn{3}{|l|}{ Kinship: } \\
\hline$($ yes $=1 ;$ no=0 $)$ & 0.62 & $(0.38-1.02)$ \\
\hline Groom's age (range $18-65$ years) & 0.95 & $(0.9-1.01)$ \\
\hline \multicolumn{3}{|l|}{ Groom's education: } \\
\hline$($ some $=1 ;$ none $=0)$ & 0.81 & $(0.46-1.42)$ \\
\hline \multicolumn{3}{|l|}{ Groom's household asset: } \\
\hline$($ some $=1 ;$ none $=0)$ & $0.59^{*}$ & $(0.39-0.9)$ \\
\hline (unknown $=1$; none $=0$ ) & 0.74 & $(0.4-1.39)$ \\
\hline Model $\chi^{2}, 8 \mathrm{df}$ & 85.3 & \\
\hline
\end{tabular}

Note: The odds ratio's of the reference groups are equal to 1.00 and consist of 'no' or 'none' (value=0) for all variables except for marriage duration, groom's age.

a births before 12 months after marriage are assumed to occur at the 12th month.

* $\quad P<0.05$

** $\quad \mathrm{P}<0.01$. 